Volume (4) No. (1) 2021

واقع تدريس الفيزياء في المرحلة الجامعية وأفاق تطويره

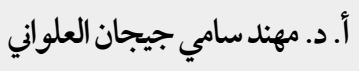

http://dx.doi.org/10.29009/ijres.4.1.4 


\section{واقع تدريس الفيزياء في المرحلة الجامعية و أفاق تطويره \\ أ. د. مهند سامي جيجان العلواني \\ عضو هيئة التدريس، جامعة الزاوية، ليبيا}

mohanadsami4@gmail.com

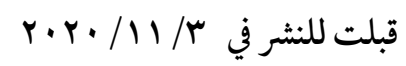

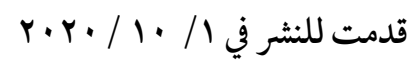

الملخص: تلخص هذه الورقة واقع تدريس الفيزياء في المرحلة الجحامعية، في ضوء تحديات الواقع والمستقبل ومواكبة التطور العلمي الذي يشهده علم الفيزياء باستمرار، حيث تلقي الضوء على هذا الو اقع من خلال بعض الاقتراحات التي من شانها أن تدفع وتطور من عملية تدريس الفيزياء في المرحلة الجامعية وللمتخصصين في هذا العلم سواء من الناحية النظرية أو العملية أو التطبيقية، من الناحية النظرية ان تستخدم التقنيات الحديثة وتطوير المقررات من خلال مواكبة التطورات العلمية الموجودة في الجامعات العالمية المتطورة. اما من الناحية العملية أن تتوفر في المختبرات حواسيب تستخدم لرسم المنحنيات البيانية واستخراج النتائج، وان تكون تلك المختبرات بجهزة بكل ما تستلزمه التجارب، وان يرتبط عمل تلك التجارب بعد المحاضرات النظرية. أما من الناحية التطبيقية و الذي يتضمن مسائل

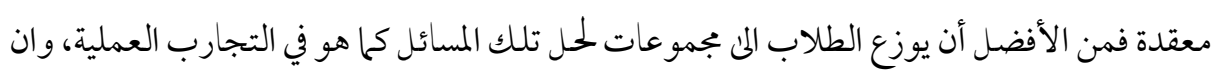
يعلن للطلاب المسائل التي ينبغي حلها قبل اسبوع حتى يكونو امستوعبين للمادة العلمية ومستعدين

الكلمات الدلالية: واقع التدريس، تدريس الفيزياء، تطوير التدريس. 


\title{
The reality of teaching physics at the undergraduate level, and Development Horizons
}

\author{
Prof.Dr Mohanad Sami Gigan Alawani \\ Professor of faculty member, Zawia University, Libya \\ mohanadsami4@gmail.com
}

Received in 1st October 2020

Accepted in 3rd November 2020

\begin{abstract}
This paper summarizes the reality of teaching physics at the undergraduate level, in light of the challenges of reality and the future and keeping pace with the scientific development that the science of physics is constantly witnessing, as it sheds light on this reality through some suggestions that would advance and develop the process of teaching physics at the university level and for specialists In this science, whether from a theoretical, practical or applied point of view, from a theoretical point of view, to use modern technologies and develop courses by keeping pace with the scientific developments in the advanced international universities. As for the practical aspect, the laboratories should have computers that are used to draw curves and extract the results, and that these laboratories should be equipped with all that is required for the experiments, and that the work of these experiments is linked after the theoretical lectures. As for the practical aspect, which includes complex problems, it is better to divide students into groups to solve those problems as it is in practical experiments, and to announce to students the questions that should be solved a week before so that they are aware of the scientific material and ready for it.
\end{abstract}

Keywords: teaching reality, physics teaching, teaching development. 
نظراً لأهمية الفيزياء ودور ها الحضاري بجا نشاهده من اختراعات للعديدمن الاجهزة الفيزيائية التي تزدادو تتطور باستمرار لتساهم بشكل فعال في التقدم العلمي والحضاري للأمم في المجالات كافة، كان من الضروري القاء الضوء علن و اقع تدريس الفيزياء في المرحلة الجامعية وآفاق تطويره. وكلنا متفقون أن مهام الجامعات في خختلف دول العالم إعداد و تخريج الأطر العلمية في الاختصاصات كافة، لذلك يجب عليها ان تكمل هذا الدور وذلك بمتابعة خرييها وإتاحة الفرصة أمامهم كي يبقوا علن اتصال مستمر مع المستجدات العلمية و التطورات الهائلة التي تحصل في جامعات الدول المتقدمة علمياً وفي مر اكز البحوث العلمية ،ويتم ذلك بالتنسيق مع وزارة التربية و التعليم لأعداد دورات التأهيل المستمر لمدرسي المدارس الثانوية الذين تخرجوا من هذه الجامعات، كماتجدر الإشارة المي اهمية احداث مكتب في كل جامعة في الجامعات يختص بمتابعة خريجيها وأماكن عملهم و ماهي ملاحظات واقتراحات رؤسائهم علن المناهج كي تؤخذ في الاعتبار عند تطوير المناهج في جامعاتنا. وحيث أن تخصص الفيزياء في كليات التربية لا يحتوي على مقررات حديثة ومتطورة التي تعالج الدراسات الرقمية، الليزر وتطبيقاته، فيزياء البلازما، أنصاف النواقل، علم البلور ات، وقد تكون بعض هذه المقررات موجودة في كليات العلوم وقد لا تكون موجودة لأنها تحتاج المى متخصص فيها وهذا ما نعاني منه. وحول تدريس الجزء النظري من مقررات الفيزياء وآفاق تطويره نستطيع القول من الضروري لأعضاء الهيئة التدريسية كافة ممن ليس لديهم إلمام بالحاسوب إتباع الدورات التدريبية التي تقام في مختلف المؤسسات، ونقترح استخدام المصطلحات العلمية باللغتين العربية والإنجليزية في المحاضرات النظرية، وهذا سيمكّن الطلاب من الاطلاع على الكتب والمجلات العلمية باللغة الإنجليزية. ولتطوير تدريس الجزء النظري من مقر رات الفيزياء نقترح: استخدام التقنيات الحديثة في المحاضرات النظرية كلما كان ذلك مكنناً مثل أجهزة الإسقاط الضوئية والحاسوب. 
تطوير مناهج بعض المقررات كلما كان ذلك ضرورياً بهدف مواكبة التطورات العلمية التي تحصل في جامعات الدول المتقدمة علمياً. التأكيد علن إجراء البحوث العلمية في الجامعات علن نطاق واسع لاسيا في مجال الفيزياء وتو فير مستلزماته. متابعة إلقاء محاضرات البحث العلمي(السيمنار) أسبوعيا لأهمية ذلك في تبادل الأفكار والمقترحات العلمية بين اعضاء هيئة التدريس. العمل علن توحيد المصطلحات العلمية باللغة العربية في جميع الجلمعات ومراكز البحوث العلمية. عقد مؤتمر دولي لتدريس الفيزياء في الجامعات للاطلاع علن التطورات والاتجاهات في تدريس الفيزياء. وحول التدريس العملي للفيزياء و آفاق تطويره: تختلف حالياً طريقة التدريس العملي للفيزياء من خختبر الما آخر، كما يختلف عدد الطلاب في كل فئة وعددهم في التجربة الواحدة، وبهدف تطوير التدريس العملي نقترح الآتي: تحديد عدد الطلاب علن التجربة الواحدة وحسب ما تقتضيه التجربة والأفضل وأن تكون بطالبين فقط. يفضل ان يقوم جميع الطلاب بإجراء التجربة العملية نفسها في الوقت نفسه إذا كانت الامكانات متاحة. أن ثُجرئ التجربة العملية بعد إلقاء المحاضرة النظرية المتعلقة بها في الجزء النظري. استخدام الحاسوب في رسم المنحنيات البيانية المتعلقة بالنتائج العملية للتجربة وهذا يتطلب وضع جهازي حاسوب في كل مختبر من مختبرات الفيزياء في السنتين الثالثة والرابعة فيزياء. يقدم الطالب تقريراً عن تجربته العملية في نهاية كل جلسة ويتم التصحيح مباشرةً من قبل الأستاذ، كما توضع الدرجة المستحقة لكل طالب في كل تجربة بعد مناقشة نتائجه العملية. 
متابعة تطوير مختبرات الفيزياءوشراء التجهيزات المخبرية الحديثة اللازمة.

$$
\text { وعن تدريس الساعات العملية التطبيقية وآفاق تطويره: }
$$

إن الساعات العملية التطبيقية خصصة لحل المسائل المتعلقة بالجزء النظري في كل من مقررات الفيزياء، وتختلف طريقة حل المسائل المخصصة من مقرر الما آخر ولكل عضو هيئة تدريس اسلوبه الخاص في الحل، وبهدف تطوير تدريس هذه الساعات التطبيقية نقترح الآتي:

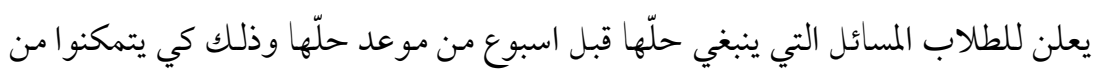
تحضير القسم النظري من المقرر المتعلق بهذه المسائل قبل التفكير بالحل. توضع درجات للطلاب الذين يحلونها من درجات اعمال السنة المخصصة للمقرر بهذه الطريقة. يتابع الطلاب بشكل يومي تحضير المحاضرات النظرية التي يلقيها اساتذتهم، وهذا يؤدي لاستيعابهم المقررات بشكل جيد.

من المناسب ان يوزع الطلاب في الساعات التطبيقية الما بجموعات كما هو الحال في الساعات العملية حتى يساعد بعضهم البعض من خلال المناقشة في الحلول المطروحة 